\title{
Extractive Strategies at Peoria Quarry, Ottowa County, Oklahoma
}

Don Dickson

Unknown

Follow this and additional works at: https://scholarworks.sfasu.edu/ita

Part of the American Material Culture Commons, Archaeological Anthropology Commons, Environmental Studies Commons, Other American Studies Commons, Other Arts and Humanities Commons, Other History of Art, Architecture, and Archaeology Commons, and the United States History Commons

Tell us how this article helped you.

This Article is brought to you for free and open access by the Center for Regional Heritage Research at SFA ScholarWorks. It has been accepted for inclusion in Index of Texas Archaeology: Open Access Gray Literature from the Lone Star State by an authorized editor of SFA ScholarWorks. For more information, please contact cdsscholarworks@sfasu.edu. 


\section{Extractive Strategies at Peoria Quarry, Ottowa County, Oklahoma \\ Creative Commons License \\ (c) $($ ) $(9)$}

This work is licensed under a Creative Commons Attribution-NonCommercial 4.0 International License 
Volume 8, Number 1

\title{
EXTRACTIVE STRATEGIES AT PEORIA QUARRY है EXTRACTIVE STRATEGIES AT PEORIA QUARRY, OTTOWA COUNTY, OKLAHOMA
}

\author{
by Don Dickson
}

Introduction

The Peoria Quarry complex was first recognized as representing prehistoric activities by geologist Walter $\mathrm{P}$. Jenny in 1891. Jenny, who was studying the zinc and lead mines in southwestern Missouri and adjacent areas, made collections from the Peoria extractive area and submitted these specimens along with an introductory letter to Mr. G. K. Gilbert of the United States Geological Survey. The latter contacted William $\mathrm{H}$. Holmes, who visited the location in late October of that year (Holmes 1894:7-8). Prior to the evaluation of Jenny, the site was referred to as "old Spanish mines" because the local populace could not attribute such extensive digging to prehistoric peoples. Some early accounts of the Peoria Quarry area greatly exaggerated the vertical and horizontal extent of excavations. For example, Nieberding (1972:146) mentions that John P. McNaughton visited these "mines" in 1877 and concluded that at least 500 to 1000 men must have been engaged in digging pits over an extended period of time in a 40 acre area. According to McNaughton, some of the shafts were 250 to 300 feet in depth, and it amazed him that the pits apparently had been excavated using stone tools. He did not mention the great quantities of lithic debitage which surrounded each pit. Holmes (1894:9), while admitting that digging at the site had been extensive, estimated that chert had been extracted from an area of no more than four or five acres and stated that the greatest depth of pits in 1891 was about five feet. He did mention that a few trenches of 100 feet or more in length could be found along the margins of the site, but stated that most evidence of digging consisted of round pits up to 40 feet in diameter. His sketch map (Holmes 1894:Plate 1) depicts the approximate extent of quarry pits and associated workshop areas. Figure 1 reproduces this sketch as well as indicates the positions of a modern county road and buried water line.

Apparently Holmes conducted test excavations in some of the pits, but the extent of such excavations is not clear from his published accounts $(1894,1919)$. His "cross sections" of pits indicate bedrock just below the surface (Holmes 1894:10); however, recent backhoe trenches dug to bury a water line across the site suggest that the chert deposits are of a residual nature in a reddish clay and that solid rock strata are not involved. Apparently the 


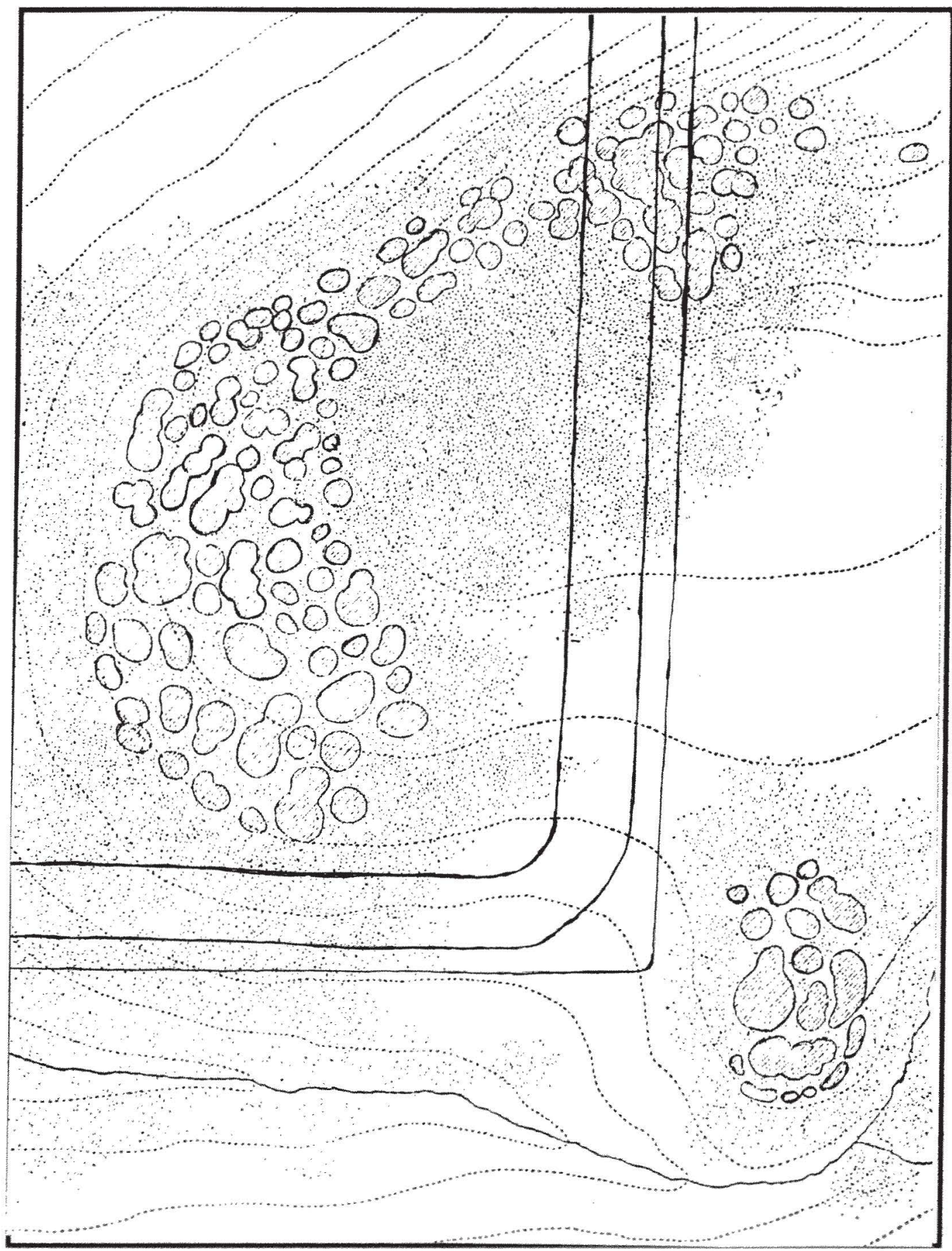

Figure 1. Sketch map of the quarry site, about 100 feet to an inch. The pitting is indicated by shaded areas and the shops are dotted (from Holmes 1894). 
Volume 8, Number 1

carbonates associated with the chert have disintegrated, leaving the chert masses surrounded by clay. Holmes did illustrate (1894:Figure 1) an antler tine found in one of the pits, which he interpreted as a pick; however, he mentions the finding of portions of a deer skeleton in another.

During the early 1960 s, the writer visited the Peoria Quarry site on several occasions, collecting samples of chert, preforms and other tools and taking photographs of the extractive area. At this time many pits were still visible and several were at least one meter deep. Most of the area was wooded. Debitage ringed each of the pits and covered spaces between these prehistoric excavations to an unknown depth. Very little grass grew on the surface, apparently due to a scarcity of soil between the chert flakes. At this time many preforms littered the surface, hammerstones of tripolized and harder chert were commonly found, and a search of the surface yielded several probable quarrying tools and two culturally diagnostic artifacts. These will be described in this brief paper

Apparently, during the 1980 s, the landowner decided to develop the quarry area. He had the trees removed, leveled the land with a bulldozer, and placed several structures on the site. Only a narrow strip of the quarry north of the county road remained fairly intact. Unfortunately, a county water line was buried in a portion of the remaining quarry area. A wonderful opportunity to study extractive strategies was missed, because this area was "surveyed" by an archeologist who apparently did not recognize the presence of this important site. By January of 1997 , over $98 \%$ of the Peoria Quarry area had been eliminated or seriously disturbed. One objective of this paper is to bring together what is known about one of Oklahoma's largest prehistoric quarry sites and the extractive strategies used to obtain knappable chert.

\section{GEOLOGICAL CONTEXT}

Holmes (1919:202) concluded that the chert-producing deposits at Peoria Quarry were upper subcarboniferous (Mississippian in modern terminology) in age. Skinner (1957:39-43) agreed that the deposits were upper Mississippian and attributed them to the Boone formation, a very thick amalgamation of chert and limestone layers. Reed et al. (1955: Plate 1) depict the area of the Peoria quarry as expressing the Boone formation. Since the 1950s, both Oklahoma and Missouri have subdivided the old Boone formation, giving formational status to such subdivisions as Bachelor, Compton, Northview, Pierson, Reeds Spring, Keokuk (or Keokuk-Burlington), Elsey, and Warsaw. Only in Arkansas is the Boone still formally recognized; however, at this time the St. Joe, with members Bachelor, Compton, Northview and Pierson, has been removed from the Boone and the 
remainder has informally been divided into "lower" (Reeds Spring equivalent) and "upper" (Keokuk or Keokuk-Burlington equivalent; Manger et al. 1988:226).

Banks (1990:27-28) suggested that the Peoria chert deposits represent an outlier of the Tahlequah member of the "Moorefield" formation. While this is certainly possible, the Peoria chert does not closely resemble chert from the Tahlequah member at the type station near Tahlequah, Oklahoma. On the other hand it is much denser and of a different texture than most of the Keokuk cherts recognized in northeastern Oklahoma. Neither does it closely resemble cherts from either the Elsey or Warsaw formations in nearby Missouri. Slocum (1955) does not indicate the presence of post-Keokuk deposits in the Peoria area in his Post Boone Outliers in Northeastern Oklahoma. Only an outlier of the Hindsville formation is shown in the Ward area, well south of Peoria. The geological map of Ottowa County published by Reed et al. (1955) depicts small outliers of both Hindsville limestone and Batesville sandstone within five miles of the extractive area but shows no outliers of postKeokuk age near the quarry. A search for parent carbonates by the writer has not been successful. Keokuk and Tahlequah carbonates can be distinguished by physical characteristics and by conodont and other fossil inclusions. It seems apparent that such deposits have been completely dissolved and the chert inclusions have been left as residuum. In fact, the surrounding clay is also probably residual also. To further complicate matters, the chert is not fossiliferous as are most Burlington and Keokuk cherts. In all directions from the slightly elevated hilltop upon which the Peoria quarry area is situated, one finds typical Keokuk chert on the surface. However, one must remember that differences in elevation may not be easy to decipher. Formations are commonly found draped over ridges and valleys produced by ancient erosion and are often quite irregular. Therefore vertical positioning cannot be used as a determining factor unless one knows what is beneath the elevated area. In this case, we cannot prove that a Tahlequah or other post-Keokuk outlier is involved. The characteristics of a particular chert reflect such depositional factors as depth of water and carbonate compensation limits. In other words, the penecontemporaneous (deposited with the carbonates) Reeds Spring cherts were deposited during a time of maximum transgression of Mississippian seas in a muddominated interval. The later KeokukBurlington diagenetic cherts (formed by replacement of carbonates) were formed during a regressive sequence when water was much shallower (Manger et al. 1988:228-229). The Peoria chert clearly is diagenetic and therefore represents either an upper Keokuk-Burlington expression or a post-Keokuk-Burlington manifestation. Until further study reveals evidence of age via fossil inclusions or by other means, the Peoria chert may best be considered as reflecting an unknown upper Mississippian component. 
Volume 8, Number I

\section{EXTRACTIVE STRATEGIES SUGGESTED BY QUARRYING TOOLS}

Although none of the quarry pits have been studied properly by a modern archeologist, several conclusions can be drawn from recent water line excavations and from apparent quarrying tools found by Holmes and by the writer. First of all, the waterline trench obviously did not encounter solid bedrock, although solid strata could exist at a greater depth. The writer was not present during the placement of this line, and was unable to view the open trench; however, the spoil clay and rock scattered about the surface indicated that large chunks of chert were surrounded by a red clay. The chunks and fragments of chert were not consolidated as one finds south of Joplin, Missouri in the Grand Falls amalgamation of cherts from several formations (Robertson 1967). The homogeneous nature of the chert suggests it is from one stratigraphic source. As Holmes recognized years ago, the white to yellowish-gray chert possesses exceptional massiveness and homogeneity, but has only moderate fracturing qualities (Holmes 1919:207). It is very difficult to produce other than thick preforms from raw Peoria chert; however, when heat treated, the chert flakes excellently. The fact that it could be obtained in large pieces made it attractive prehistorically.

In all probability the first Native American groups to exploit the Peoria extractive area simply picked up chert exposed on the surface. Later peoples were forced to dig into the soil to obtain loose chunks of residuum. Holmes (1894:9) believed that none of the pits were over 10 or 12 feet deep, but it is impossible to do more than speculate without excavating one or more of the pits. The quantity of usable chert exposed while digging the water line suggests that digging much over a meter deep would have been unnecessary. Anyhow, the quarrying tools can be divided into two broad categories. First, were those tools used to remove soil and undesirable residuum? As Holmes suggested, antler tines may have been used as picks. Also, a few chert picks were employed (Figure 2). The most common digging tool at Peoria apparently was a chert hoe-like tool with a constricted midsection and a thinned upper margin. The opposite end often features evidence of battering, presumably from contact with other rocks in the soil. Apparently an "L-shaped" haft was used, with the short portion being split and attached by binding about the constriction. Holmes found one of these tools, although he considered it to be a reject or possibly a preform for an ax (Holmes 1894:Plate VIII). During the early 1960 s, the writer found three similar examples on the surface (Figure 3). My interpretation is that these tools were used in digging the pits much as one might use a hoe. The four illustrated examples, including the specimen found by Holmes, are depicted at one half scale, and Table 1 gives dimensions of illustrated examples. It is suggested here that hoe-like tools and antler or chert picks were used to loosen the soil and undesirable residuum. Then it seems probable that baskets or some other containers were 


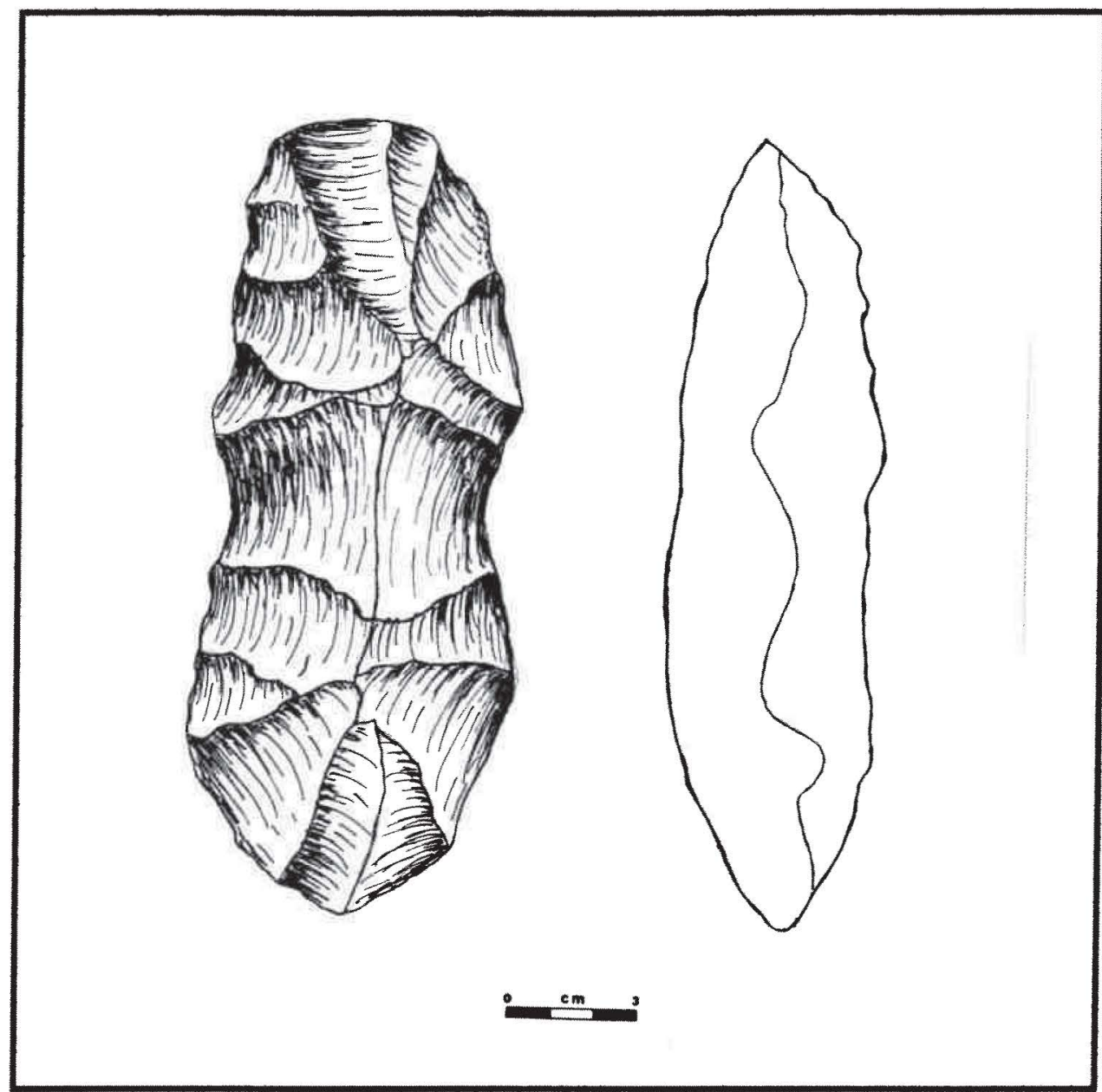

Figure 2. Chert pick found by Holmes (adapted from Holmes 1894: Plate VIII).

used to carry the loose material outside of the pit area. Hammerstones were then used to break or spall the large pieces of chert residuum which could not be removed intact. The backhoe or trenching machine used to bury the water line brought to the surface chunks of chert up to $50 \mathrm{~cm}$ in length. Smaller hammerstones were employed to test chert quality and to rough out preforms which would be heat treated and further reduced elsewhere.
While some evidence of heat treatment can be observed on some flakes, this actually may be the result of historic and prehistoric forest fires. Since it is hypothesized that chunks of usable chert residuum were surrounded by residual clay, it may well be that antler wedges such as were used to remove pieces of Threemile chert at 14PO57 in Kansas (Banks 1990:102) were not needed or used at the Peoria quarry. 


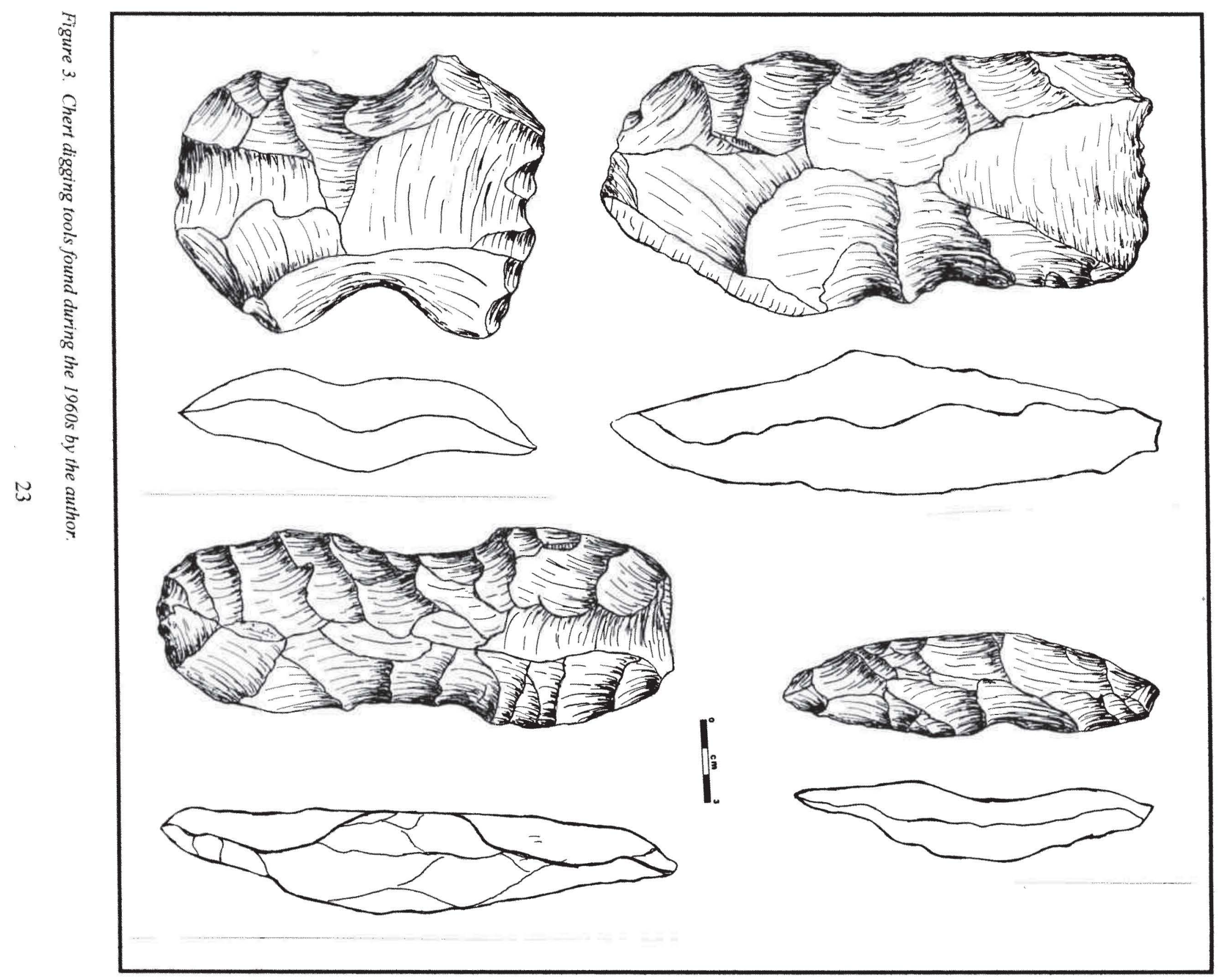


Table 1. Quarrying tools shown at one half scale.

\begin{tabular}{|c|c|c|c|}
\hline \hline $\begin{array}{c}\text { Catalog } \\
\text { number }\end{array}$ & Tool category & $\begin{array}{c}\text { Dimensions } \\
(\mathbf{c m})\end{array}$ & Chert type \\
\hline \hline $34 \mathrm{P} 513$ & chert pick & $13.3 \times 3.8 \times 2.4$ & Peoria \\
$34 \mathrm{P} 514$ & chert digging tool & $13.8 \times 9.6 \times 3.8$ & Peoria \\
$34 \mathrm{P} 515$ & chert digging tool & $21.0 \times 10.0 \times 5.2$ & Peoria \\
$34 \mathrm{P} 516$ & chert digging tool & $19.2 \times 7.2 \times 3.8$ & Peoria \\
after Holmes & chert digging tool & $18.6 \times 7.6 \times 4.8$ & Peoria? \\
$34 \mathrm{P} 517$ & hammerstone & $12.5 \times 10.7 \times 6.4$ & Peoria \\
$34 \mathrm{P} 518$ & hammerstone & $9.0 \times 8.4 \times 8.4$ & tripolized Peoria \\
\hline \hline
\end{tabular}

The second category of extractive tool is the hammerstone. While smaller examples of such implements probably were used more in knapping chert extracted from the pits, the large specimens certainly would have been effective in breaking spalls from chert chunks too large to remove in one piece. Figure 4 illustrates two medium sized chert hammerstones at one half scale. Both larger and smaller hammerstones were noticed in the 1960s visits, but these were not collected at the time. That some very large hammerstones were used in quarrying activities is indicated by one syenite hammerstone found by the writer at Spanish Mountain near Magnet Cove, Arkansas, which was almost $25 \mathrm{~cm}$ in diameter and weighed 44 pounds $(19,958$ g). All of the hammerstones noted at Peoria were of either tripolized or solid chert.

Holmes (1894:15) reported finding preforms as much as $45 \mathrm{~cm}$ long, $28 \mathrm{~cm}$ wide and $15 \mathrm{~cm}$ thick. He collected 30 boxes of preforms, mostly between $12 \mathrm{~cm}$ and 20 $\mathrm{cm}$ in length, and no doubt others have made collections at the site. However, in the 1960 s many preforms were still obtainable from the surface, most of which were elliptical or roughly triangular in shape and between $10 \mathrm{~cm}$ and $20 \mathrm{~cm}$ in length. No attempt will be made to illustrate these preforms in this report; however, Holmes depicts many in two publications (1894, 1919). 


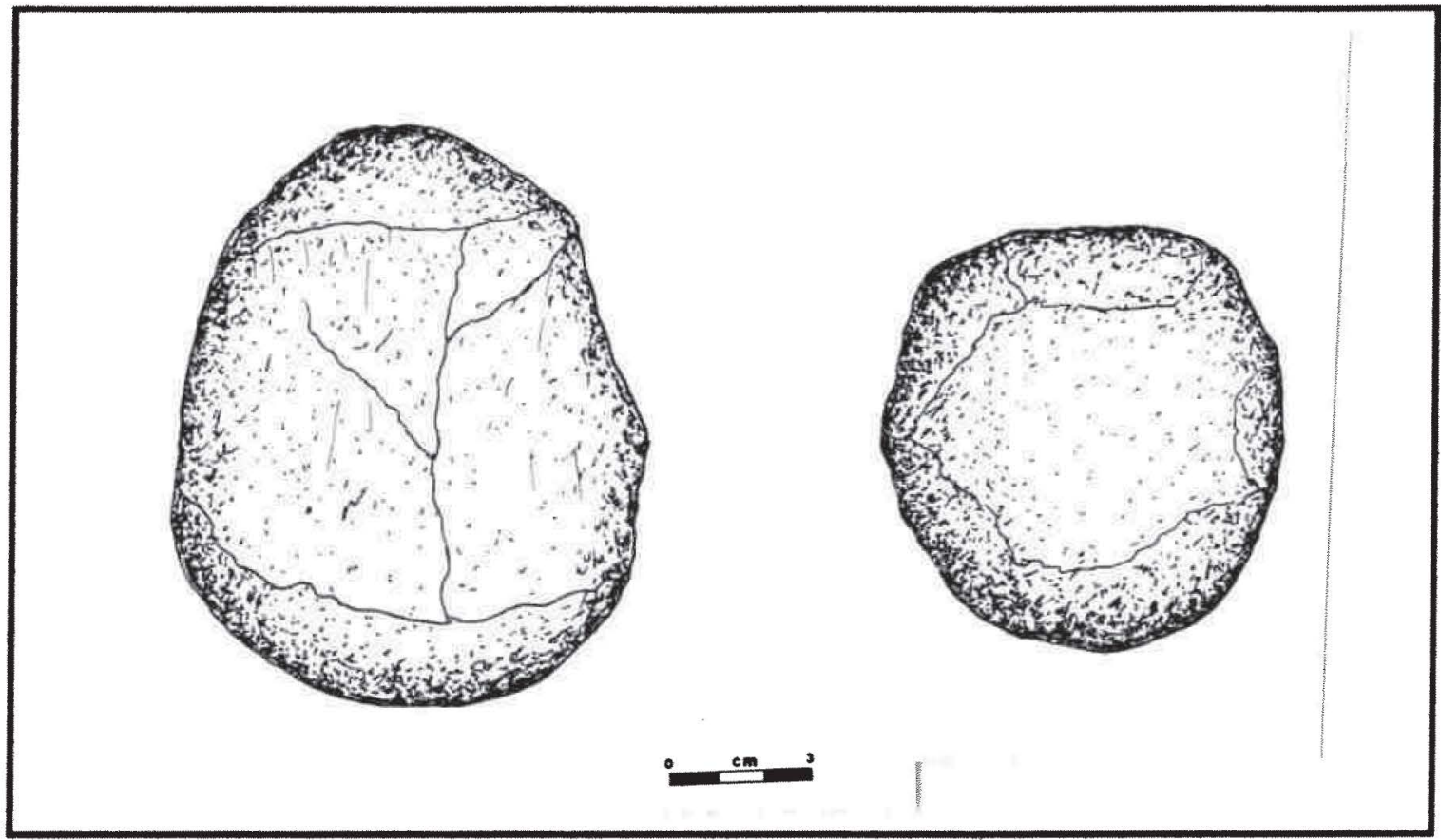

Figure 4. Hammerstones collected by the author during the 1960s.

\section{CULTURES WHO USED THE QUARRY}

Holmes (1894:16) stated that no finished implements had been collected from the quarry, although he depicts in Figure 7 a fairly thin leaf shaped biface which probably had been completed. In three visits to the site in the 1960s the writer found one damaged hafted biface (Figure $5 \mathrm{a}$ ) and one complete scraper (Figure 5b). Both are depicted full scale. The hafted biface seems to be of a Late Archaic type. Although the stem is damaged and the tip is missing, the biface featured an expanding stem formed by corner notching. As found, the artifact measures $7.5 \mathrm{~cm} \times 3.5 \mathrm{~cm} \times 1.2 \mathrm{~cm}$. It resembles such Late Archaic types as Stone
Corner Notched and Big Creek. The chert is local Keokuk, not Peoria, chert.

A second culturally diagnostic specimen collected by the writer during his 1960 s visits to the site is a large end scraper (Figure 5b). This specimen most closely resembles scrapers from the Deer Creek site (34KA3), a protohistoric site in Kay County, Oklahoma (Sudbury 1976: Figures 30,31) and scrapers from the Little Deer site (34CU10), another protohistoric site in Custer County, Oklahoma (Brooks 1996: 73-92). The specimen, made from a curved flake of Peoria chert, measures 6.8 


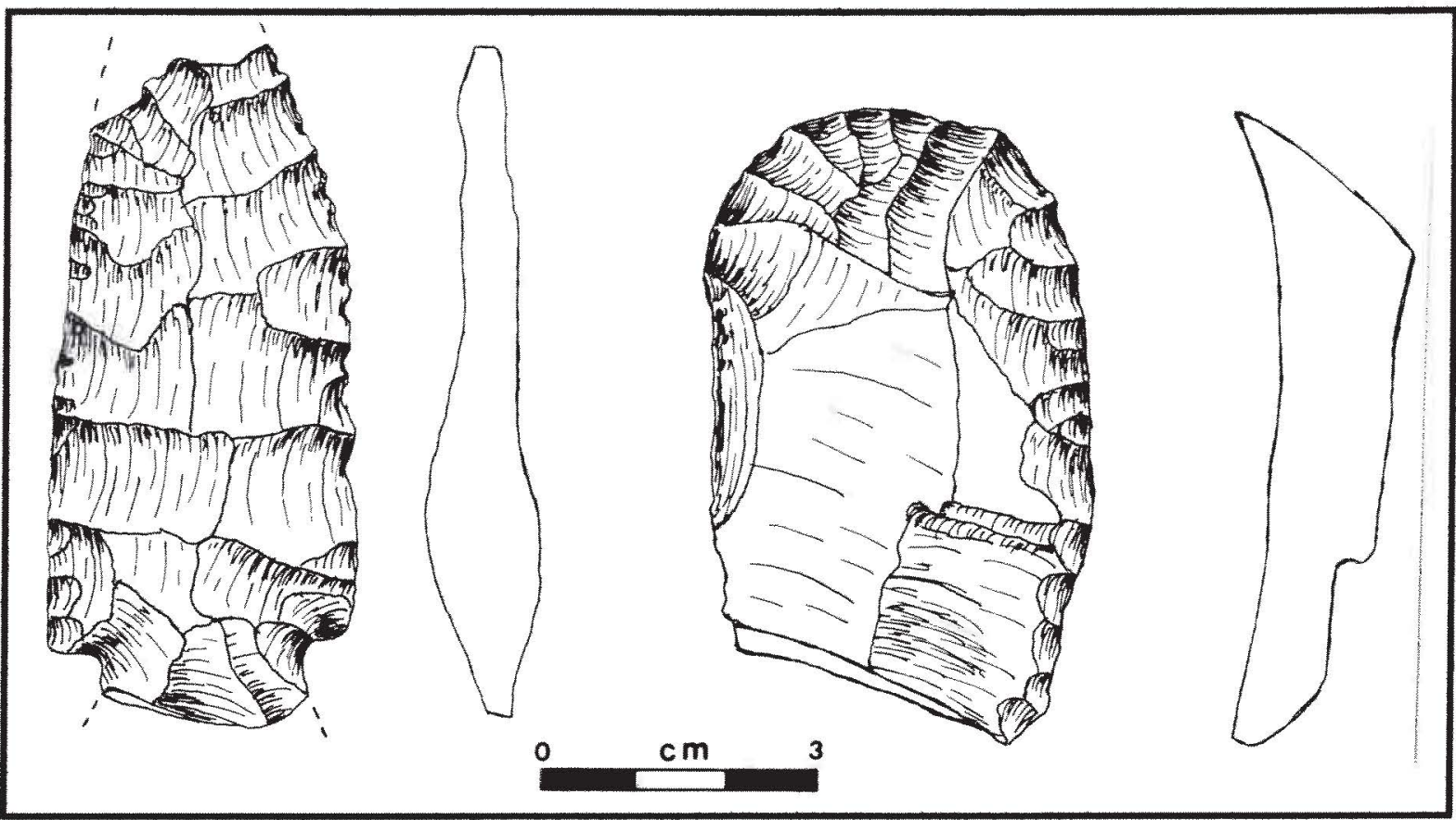

Figure 5. Completed stone tools collected by the author.

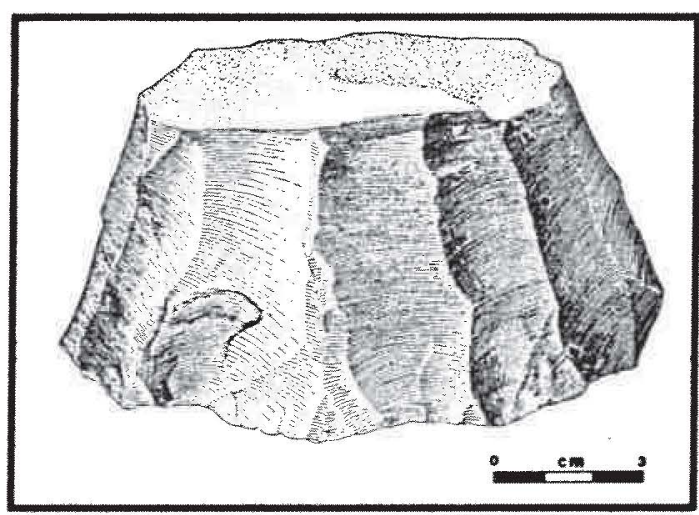

Figure 6. Example of polyhedral core illustrated by Holmes (1894: Figure 87).

$\mathrm{cm} \times 4.3 \mathrm{~cm} \times 1.7 \mathrm{~cm}$. A protohistoric use of this quarry is supported by the statement of Holmes (1894:12) that some of the workshop areas seemed undisturbed and the associated chert had not changed color very much.

A third possibly diagnostic specimen category was illustrated by Holmes (1894: Plate X). Two examples of polyhedral cores, from which many blades had been removed, were depicted in this plate. One of these cores is shown in Figure 6. These specimens suggest a Middle Woodland affiliation. Thus, one may tentatively say that the Peoria Quarry was used by prehistoric peoples at least during Late Archaic and Woodland times and by protohistoric groups in the area. Future work at the site may extend this provisional chronology. 
Volume 8, Number 1

\section{REFERENCES CITED}

Banks, Larry D.

1990 From Mountain Peaks to Alligator Stomachs: A Review of Lithic Sources in the Trans-Mississippi South, the Southern Plains, and Adjacent Southwest. Oklahoma Anthropological Society Memoir 4.

Brooks, Robert L.

1996 A Protohistoric Tool Kit: Scrapers from the Little Deer Site (34CU10). Bulletin of the Oklahoma Anthropological Society 45:73-92.

Holmes, William $\mathrm{H}$.

1894 An Ancient Quarry in Indian Territory. Bureau of American Ethnology Bulletin 21

1919 Handbook of Aboriginal American Antiquities; Part 1: Introduction, the Lithic Industries. Bureau of American Ethnology Bulletin 60:196-209

Manger, Walter L., Phillip R. Shelby and Steve G. Farris

1988 Devonian-Lower Mississippian Lithostratigraphy, Northwestern
Arkansas. The Compass 64(4):223-231

Nieberding, Velma

1972 Old Peoria: A Mother of Mining Camps. The Chronicles of Oklahoma 50(2).

Reed, Edwin W., Stuart L. Schoff, and Carl C. Branson

1955 Ground Water Resources of Ottowa County, Oklahoma. Oklahoma Geological Survey Bulletin 72. Norman.

Robertson, Charles E.

1967 The Elsey Formation and its Relationship to the Grand Falls Chert. Report of Investigations 38. Missouri Geological Survey and Water Resources, Rolla

Skinner, Hubert C.

1957 Two Artifact Flints of Oklahoma. Bulletin of the Oklahoma Anthropological Society 5:39-43.

Slocum, R. C.

1955 Post-Boone Outliers of Northeastern Oklahoma. Oklahoma Geological Survey Circular 35. Norman. 